\title{
Observasi Dalam Mencipta Karya Seni
}

\author{
Nick Soedarso; Barry Carvey \\ Jurusan Desain Komunikasi Visual, School of Design, BINUS University \\ Jln. K.H. Syahdan No. 9, Kemanggisan Jakarta Barat \\ nsoedarso@binus.edu; bcarvey@binus.edu
}

\begin{abstract}
In the beginning of creating a work of art, an observation of the problem is needed. A new representation of an existing form, would not become a newness if not display novelty and actuality, as it will only produce something similar, and repetition, so it will not be a result of creativity.

Keywords: observation, art, creativity

ABSTRAK

Awal mencipta sebuah karya seni, diperlukan sebuah observasi pada sebuah objek atau masalah yang ditemukan. Sebuah representasi baru dari suatu bentuk yang sudah ada, tidak akan terwujud bila tidak menampilkan kebaruan dan aktualitas, karena hanya akan menghasilkan sesuatu yang sama dan pengulangan, sehingga tidak akan menjadi sebuah hasil kreativitas.
\end{abstract}

Kata kunci: observasi, seni, kreativitas 


\section{PENDAHULUAN}

Upaya menciptakan sebuah desain yang baik pasti memerlukan sebuah proses. Proses ini dapat disebut dengan proses kreatif. Proses kreatif sendiri diperlukan berbagai macam persiapan, salah satunya adalah observasi. Observasi berasal dari kata kerja to observe, yaitu kegiatan mengamati sesuatu, seperti mengamati seseorang, situasi, tempat dan sebagainya dengan saksama dan cermat sampai menemukan intisari dari sebuah masalah. Pengalaman dalam pengamatan secara cermat dalam sebuah desain maka akan menemukan insight sebuah karya seni, yaitu suatu pengalaman baru yang sifatnya esensial dan fundamental. Pengamatan ini bertujuan untuk menemukan intisari dalam sebuah makna karya seni yang dihasilkan.

Setiap sebuah peristiwa yang terjadi dapat membuat sesuatu yang tidak pernah ada menjadi sesuatu yang nyata. Segala sesuatu ada karena adanya pengamatan yang dilakukan oleh manusia. Pernyataan tersebut dapat dirasakan setiap saat di kehidupan manusia, seperti sebuah pertemuan yang dialami oleh dua orang untuk yang pertama kali. Bila seseorang tidak pernah bertemu satu dengan yang lain maka masing-masing pribadi itu tidak pernah ada. Sebuah pengamatan mendalam yang dilakukan bisa menjadi sebuah pengalaman yang luar biasa dan bisa mendapatkan suatu pengalaman yang baru bagi hidup. Dan apapun yang dicermati secara mendalam akan menjadi sebuah virtual potensial. Sama halnya seperti sebuah boneka dari Eropa (Nesting Doll) ini, ketika kita hanya melihat dan memerhatikan bentuk, warna, tekstur dan tingginya maka boneka ini hanya terlihat seperti biasanya saja. Diam tidak bergerak, bentuknya yang sederhana dengan lukisan atau gambar di lapisan materialnya. Tetapi bila kita mengamati, mempelajari dan menggalinya maka kita akan mendapatkan bahwa boneka ini memiliki keunikan tersendiri. Boneka ini memiliki isi yang berlapis-lapis. Sama halnya dengan kita mengenal seseorang, jika kita belum mengenalnya, maka yang kita lihat hanyalah tampilan luarnya secara fisik. Kita tidak akan mengetahui karakter, isi hati, pemikiran, kehidupan dan lainnya dari seseorang itu jika kita tidak mengenalnya lebih dalam atau menggali informasi darinya, disini berarti kita butuh pengamatan (observasi) lebih dari biasanya. Boneka Matryoshka memberikan kita gambaran, bahwa kita menjadi sadar akan adanya kehadiran fisik dari boneka tersebut. Dapat melihat warna, garis pada bagian tubuhnya, ekspresinya dan inilah proses quantum self, dari tidak ada menjadi ada. Boneka ini menjadi sebuah eksistensi dalam konsep quantum self (lihat gambar 1).

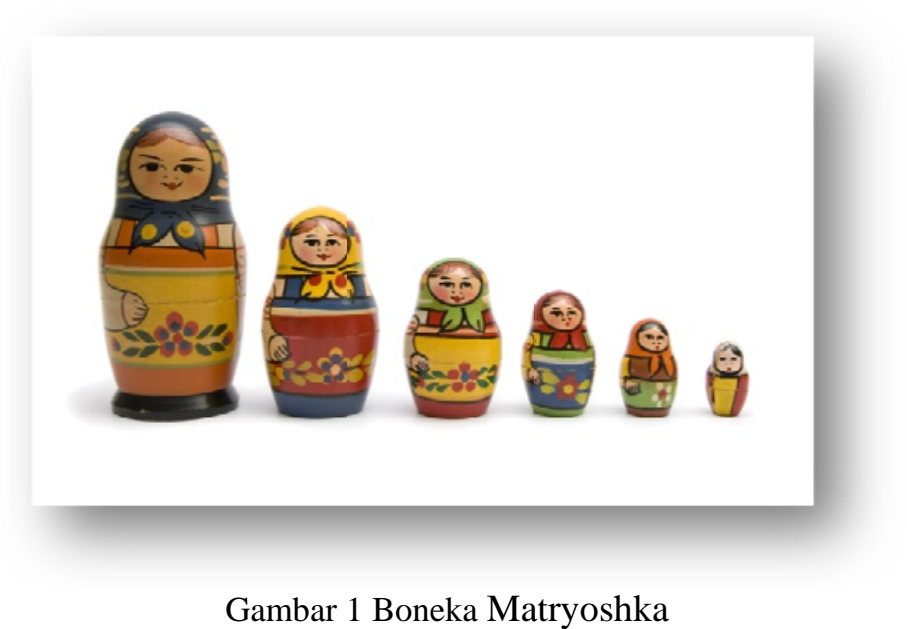

Jika kita memehatikan banyak hal, kehadiran kita di dunia ini akan semakin menjadi terlihat tidak bermakna atau absurd. Hal ini harus didasari dengan penelitian setiap individunya untuk menemukan sebuah makna tersendiri dalam hidup masing-masing individu. 
Dengan metode yang berbeda ini makan teori quantum seni tentang pengamatan dapat dijadikan sebagai materi ajar, menjadi ilmu yang kognitif atau ilmiah. Tentunya sebuah penelitian harus didasari dengan dasar-dasar pengamatan, Baik secara teoretis ataupun secara praktisnya. Jika hal ini dikombinasikan maka sebuah penelitian akan dapat menghasilkan sesuatu yang bermanfaat. Bagi setiap individu tentunya penemuan jati diri berarti mengamati setiap tingkah laku kita, perilaku kita, dari situ kita akan mendapati bagaimana diri kita dapat merespons rangsangan dari luar. Jika kita lebih mengenali diri kita sendiri secara pribadi, maka kita dapat menanggapi hal-hal yang terjadi di luar kita secara tenang. Inilah proses yang dinamakan "melihat ke dalam" atau Insight.

\section{METODE PENELITIAN}

Artikel ini berdasarkan studi literatur, yang bersumber dari pencarian referensi cetak dan elektronik. Selain itu, penelitian ini bersumber dari pengalaman dalam mengikuti perkuliahan Pascasarjana Mata Kuliah Metode Penciptaan Seni.

\section{HASIL DAN PEMBAHASAN}

\section{Brainstorming}

Brainstorming merupakan sebuah cara yang dilakukan untuk mencari sebuah ide untuk memecahkan masalah yang ada. Biasanya brainstorming dilakukan dalam sebuah kelompok yang dibentuk untuk memecahkan semua masalah tertentu yang sedang di hadapi dengan cara mengumpulkan data data ide yang spontan, bebas dan liar dimana muncul semua ide yang terlintas di pikiran dari sebuah pengamatan pengamatan yang sudah dilalui.

Pengumpulan ide yang dilakukan oleh orang orang dalam sebuah kelompok diyakini lebih efektif daripada individu yang melakukan aktivitas pengumpulan ide. Ini dikarenakan setiap pengamatan setiap individu bisa berbeda dengan individu individu yang lainnya. Dan, ketika individu individu ini berkumpul dan membentuk sebuah kelompok baru, hasil yang didapatkan akan semakin maksimal dan pengumpulan data akan semakin bervariasi. Hasil ini yang kemudian akan dipilih untuk digunakan untuk memecahkan masalah yang ada.

Pada prinsipnya, brainstorming merupakan cara untuk mengemukakan pendapat dengan pendekatan imajinatif dan liar, dimana tidak ada ide yang sudah terstruktur/terpola, tetapi bisa inovatif dan menghasilkan sebuah gagasan gagasan baru yang tidak biasa. Profesor Dwi Marianto mengatakan dalam buku Quantum Seni, menuliskan dengan curhat pendapat (brainstorming), orang mengaktifkan mata pikiran, mata hati, mata intuisi serta mata bawah sadar untuk bersinergi mencari kemungkinankemungkinan dalam pemecahan masalah.

Brainstorming pertama kali dikembangkan oleh Alex Faickney Osborn pada tahun 1953 yang dituliskan dalam buku Applied Imagination. Dalam buku ini, Osborn tidak hanya mengusulkan metode ini, tetapi juga membuat aturan yang efektif dalam melakukan sebuah brainstorming berkelompok, yaitu menerima semua ide yang ada, mencari ide sebanyak-banyaknya, membangun ide satu sama lain, dan berupaya mendorong keluar ide-ide liar yang berlebihan. Mengumpulkan ide sebanyak-banyaknya akan menciptakan sebuah ide yang baik, karena dengan kuantitas akan dihasilkan sebuah kualitas. 
Sebagai salah satu cara untuk memunculkan ide-ide kreatif, brainstorming dapat dilakukan dengan penerapan dari pemahaman filosofis Appolonian dan Dionysian yang masing masing mempunyai pola pikir yang berbeda.

Terdapat dua macam brainstorming, yaitu: self-brainstorming, yang artinya kita secara individu mencoba untuk menuliskan atau merekam banyak ide yang terus muncul dari isi kepala; team - brainstorming, yang artinya menggabungkan satu ide dengan kelompok-kelompok ide lainnya dan biasanya untuk kebutuhan aturan formal, agar dapat bekerja dengan lancar. Perhatikan gambar proses pengumpulan ide (brainstorming) berikut.

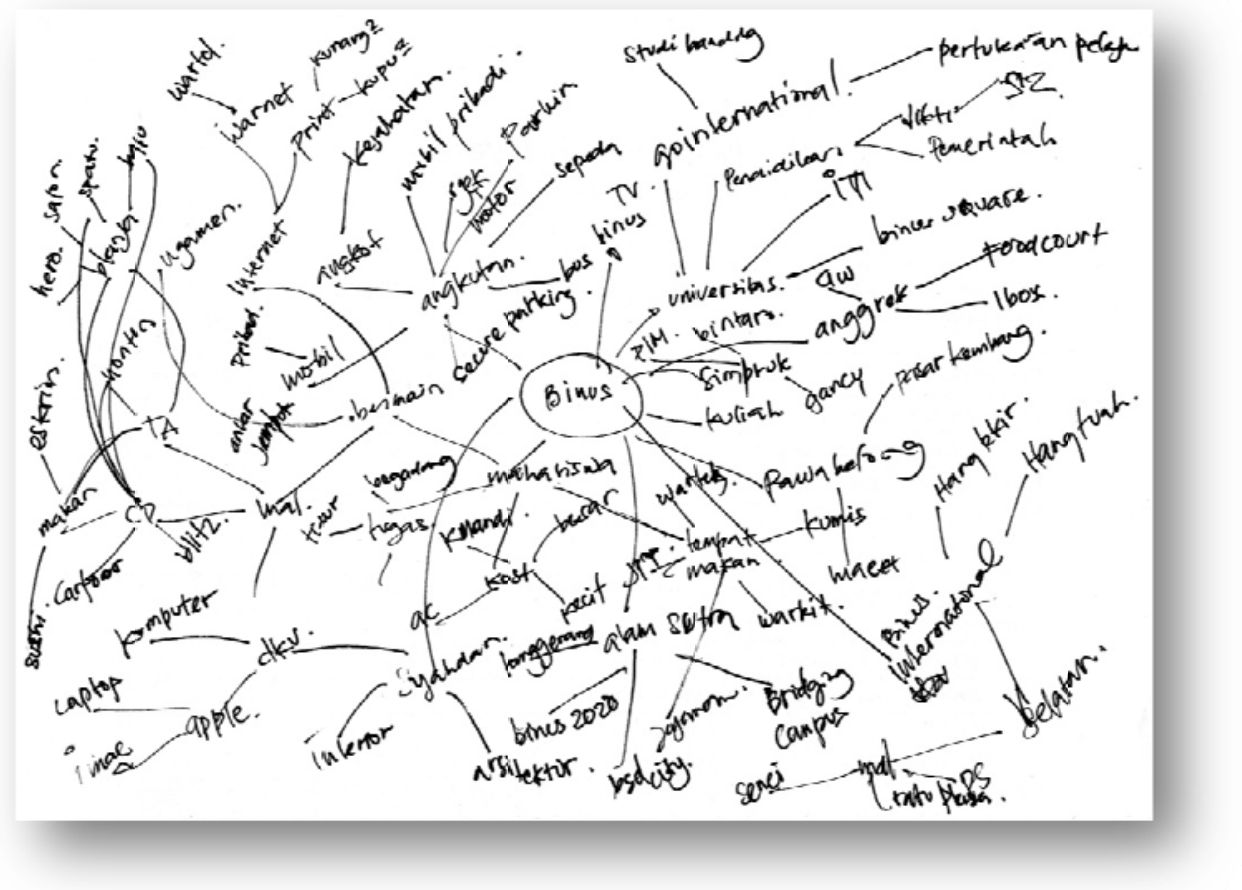

Gambar 2 Brainstorming secara liar

Bagaimana cara kita menuangkan lompatan-lompatan ide dalam suatu kertas yang ternyata menghasilkan banyak sekali jawaban yang tidak pernah kita bayangkan sebelumnya. Ketika dibatasi oleh waktu, proses sel-brainstorming harus dibiarkan liar. Proses itu tergambar dengan sendirinya tanpa harus tertata dengan rapih. Maka, hasil dari ide - ide tersebut akan sangat liar juga hasilnya. Kita memberikan waktu kepada otak untuk menuangkan isi kepala sebebas-bebasnya. Ketika kita berani mencoba untuk melepaskan ide-ide liar, membiarkannya bereksplorasi, tanpa disadari kita akan menemukan beberapa hal yang jauh di luar dari nalar logika kita. Terkadang insting dan naluri dapat membawa kita ke suatu fase yang mengejutkan.

Beberapa pendekatan untuk memaksimalkan teknik brainstorming, yaitu: brainwriting, artinya menggunakan pendekatan yang ditulis untuk brainstorming untuk menghasilkan dan mengembangkan ide - ide. Hal ini dapat membantu kita mendapatkan ide dan mengembangkan ide tersebut secara mendalam. Teknik tangga, hal ini meningkatkan kontribusi anggota kelompok lebih tenang, dengan memperkenalkan gagasan satu orang pada suatu waktu. Otak - jaring, hampir serupa dengan teknik hand-writing tetapi menggunakan suatu dokumen elektronik yang disimpan pada server pusat. Pendekatan "slip the Crawford" membantu kita mendapatkan banyak ide dari semua peserta sesi dan memberi kita pandangan dari popularitas masing-masing gagasan. 
Pengelompokan dapat kita lakukan setelah kita membuat skema brainstorming. Beberapa ide yang dikira serupa dapat dikategorikan. Pengelompokan tersebut dilakukan dengan cara memberikan lingkaran warna pada ide-ide yang sekiranya dapat kita kategorikan. Kategori-kategori ini menjadi segmentasi yang dapat membantu proses analisis berikutnya.

Di mitologi Yunani, Apollo dan Dionysius adalah putra dari dewa tertinggi Zeus. Appolo merupakan Dewa Matahari dan mimpi, menyukai musik, harmoni, puisi, dan teratur. Sedangkan Dionisius adalah Dewa Anggur, yang mempunyai jiwa ekspresif, menyukai kebebasan, liar, dan bersenang senang.

Pemahaman yang mengacu kepada kedua pemikiran Apollo dan Dionysius disebut juga dengan aliran paham Apollonis dan paham Dionysian. Dalam proses curhat pendapat atau yang lebih popular dengan istilah brainstorming ini, bisa digunakan dua paham tersebut. Paham Dionysian dapat digunakan pada tahap awal untuk memunculkan ide-ide yang liar, bebas, dan inovatif serta ide-ide yang tidak pernah terbayangkan sebelumnya karena sebuah keberanian untuk keluar dari kotak untuk memahami keadaan sangat penting dalam proses menemukan sesuatu yang baru dan inovatif. Setelah ide-ide bebas dan liar sudah terkumpul, kita dapat mengelompokkan masing masing ide dengan paham Apollonian yang teratur dan mengotak-ngotakkan ide tersebut menjadi suatu hasil yang terbaik dan kemudian dapat dipilih ide yang terbaik untuk dijalankan.

\section{Apollonian}

Apollo merupakan salah satu tokoh penting dan kompleks dari dewa-dewi dan tokoh mitologi dari bangsa Yunani kuno dan Romawi. Apollo juga merupakan tokoh ideal yang dijadikan gambaran dari kouros yang berwujud patung pria pada masa Archais. Apollo biasanya dikenal sebagai dewa cahaya dan dewa matahari, dewa kebenaran dan ramalan, dewa penyembuh, dewa pembawa wabah, dewa musik, dewa penyair, dan banyak julukan lainnya. Apollo merupakan putra dari dewa Zeus dan Leto, Ia juga memiliki seorang saudari kembar yaitu Artemis, sang pemburu suci. Apollo dikenal sebagai Apulu oleh bangsa Etrusca yang mendapat pengaruh dari Yunani.

Pengobatan dan penyembuhan sering dihubungkan dengan Apollo, baik melalui dirinya sendiri sebagai dewa atau penyembuhan melalui putranya Asclepius. Akan tetapi, Apollo sendiri juga sering dikenal sebagai dewa yang memiliki kemampuan untuk membawa penyakit dan wabah kematian. Sebagai pemimpin dari paduan suara Muses (Apollon Musegetes), Apollo berfungsi sebagai dewa pelindung musik dan puisi. Dewa Hermes menciptakan alat musik kecapi atau lira untuknya, dimana alat musik tersebut kemudian menjadi atribut yang biasa digunakan oleh Apollo.

Berdasarkan cerita mitologi Yunani, Apollo dan Artemis merupakan anak kembar dari dewa Zeus dan Leto, seorang titaness atau raksasa wanita keturunan sang langit, Ouranos dan sang bumi, Gaia yang memimpin sebelum para dewa Olympian berkuasa. Ketika dewi Hera mengetahui bahwa Leto mengandung, ia segera mengusir Leto dari daratan bumi. Kemudian di dalam pengembaraannya, Leto menemukan pulau baru yang mengapung, yaitu pulau Delos dimana pulau tersebut bukan daratan atau pulau yang sesungguhnya. Ia kemudian melahirkan di sana dan diterima kehadirannya oleh masyarakat setelah Leto menjanjikan bahwa kelak putranya akan selalu membantu dan bisa diandalkan oleh kota tersebut. Kemudian dewa Zeus mengamankan pulau Delos sebagai daratan yang sesungguhnya dengan membuatnya kokoh hingga ke dasar samudra dan tidak lagi mengapung. Pulau ini nantinya akan menjadi sangat suci bagi Apollo. Berdasarkan cerita mitologi yang ada, para peneliti menuliskan bahwa Artemis terlahir lebih dahulu dari Apollo. Apollo dilahirkan pada hari ketujuh dari bulan Thargelion atau bulan Bysios - berdasarkan dari tradisi Delian. Hari ke-tujuh dan hari kedua puluh yang merupakan hari bulan penuh baru kemudian menjadi hari yang suci bagi Apollo. 


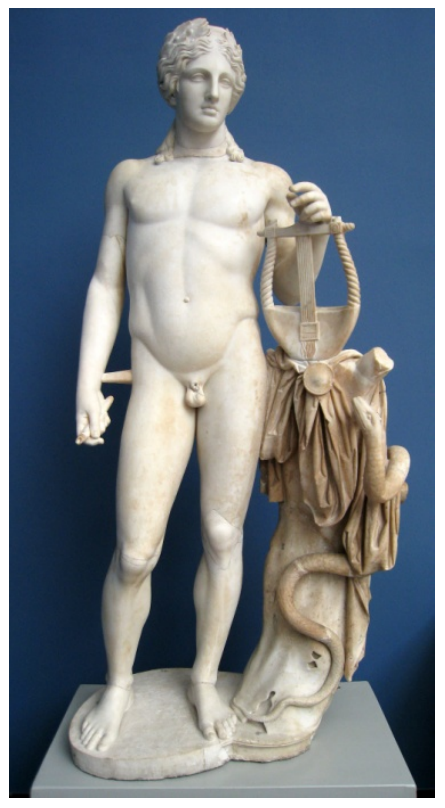

Gambar 3 Apollo

Empat hari setelah kelahirannya, Apollo berhasil membunuh naga bumi raksasa, Python, yang hidup di Delphi dekat dengan mata air Castalian. Mata air ini merupakan sumber mata air yang menyemburkan uap yang menyebabkan peramal di Delphi dapat memberikan ramalannya. Hera mengirimkan ular naga tersebut untuk membunuh Leto. Untuk melindungi ibunya, Apollo meminta sebuah busur dan anak panah dari Hephaestus. Setelah menerimanya, Apollo menyudutkan Python di gua suci dekat Delphi. Apollo kemudian berhasil membunuh Python namun harus dihukum karenanya, hal ini disebabkan Python merupakan anak dari Gaia, sang bumi. Hera kemudian mengirim raksasa Tityos untuk membunuh Leto. Kali ini Apollo dibantu oleh saudarinya, Artemis untuk melindungi ibunya. Selama pertarungan, Zeus akhirnya mengirimkan bantuannya dan membuang Tityos turun ke Tartarus. Apollo kemudian juga terlibat di perang Trojan, Apollo menembakkan anak panah yang telah diinfeksi oleh wabah penyakit ke perkemahan Yunani sebagai pembalasan terhadap penghinaan Agamemnon kepada Chryses, seorang pendeta dari Apollo yang putrinya ditangkap.

Cerita mitologi mengenai alat musik lira atau kecapi milik Apollo dimulai dari kisah kelahiran Hermes di gunung Cyllene di Arcadia. Cerita tersebut dikisahkan pada himne Homeric kepada Hermes. Ibunya yang bernama Maia telah dihamili oleh Zeus. Maia kemudian membungkus bayinya dengan selimut, namun Hermes melarikan diri ketika Maia tertidur. Hermes kemudian lari ke Thessaly, dimana Apollo sedang menggembalakan hewan ternaknya. Bayi Hermes kemudian mencuri beberapa ekor sapi milik Apollo dan membawanya ke sebuah gua di hutan dekat Pylos untuk menutupi jejaknya. Di dalam gua tersebut, Hermes menemukan seekor kura-kura dan membunuhnya, ia kemudian menyingkirkan organ dalam tubuh hewan tersebut. Ia menggunakan salah satu dari usus sapi dan menggunakan cangkang kura-kura tersebut untuk membuat lira pertamanya. Apollo mengeluh pada Maia bahwa putranya telah mencuri hewan ternaknya, namun Hermes telah mengganti selimut yang digunakan oleh Maia untuk membungkus dirinya, sehingga Maia menolak untuk mempercayai laporan Apollo. Zeus kemudian melibatkan diri dan mendukung Apollo dengan menyatakan bahwa Ia melihat kejadian tersebut. Hermes kemudian mulai memaikan musik dari lira yang diciptakannya. Apollo, sang dewa musik, langsung jatuh cinta dengan alat musik tersebut dan menawarkan untuk menyelesaikan masalah pencurian hewan ternak tersebut dengan pertukaran adil antara ternak dan alat musik lira tersebut. Sejak saat itu, Apollo kemudian menjadi master dari alat musik lira. 


\section{Dionisian}

Dionysus merupakan dewa pemetik anggur, pembuat minuman wine, dan dewa minuman anggur atau wine yang menjadi ritual kegilaan dan ekstasi pada cerita mitologi Yunani. Dionysus juga dikenal dengan sebutan 'dewa bertanduk kerbau' karena ia sering muncul dengan mengambil wujud dari hewan ini. Pada cerita mitologi Romawi, Dionysus direpresentasikan oleh dewa Bacchus. Mulanya Dionysus memiliki peran yang hampir mirip dengan dewi Demeter (dewi bumi) pada kisah mitologi tersebut. Para pengikutnya kemudian mengembangkan karakter Dionysus menjadi penyelamat pribadi mereka, khususnya para pengikut wanita yang dikenal sebagai Maenads.

Para pengikut awal dari Dionysus menggambarkannya sebagai seorang pria dewasa, berjanggut dan berjubah. Ia memegang tongkat adas yang memiliki buah cemara di atasnya dan dikenal sebagai sebuah thyrsus. Gambaran Dionysus kemudian berubah dan menunjukkannya dengan rupa tanpa janggut, tampak sensual, telanjang atau setengah telanjang dengan kemudaan yang khas. Beberapa literatur menggambarkan Dionysus sebagai pria yang bersifat kewanitaan.

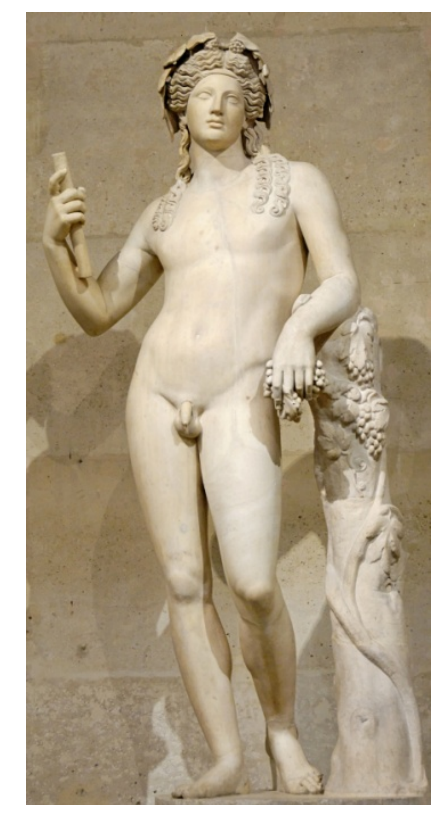

Gambar 4 Dionysus

Berdasarkan cerita mitologi, Dionysus memiliki kelahiran yang aneh sehingga mempersulit posisinya di kuil Olympian. Ibunya merupakan seorang manusia biasa, Semele, putri dari raja Cadmus dari Thebes, dan ayahnya adalah dewa Zeus, raja dari para dewa. Kemudian istri Zeus, Hera mengetahui adanya perselingkuhan ini ketika Semele hamil. Muncul dengan wujud sebagai seorang nenek tua, Hera kemudian berteman dengan Semele, lalu ia mencoba memastikan kebenaran bahwa anak yang ada di dalam kandungan Semele merupakan anak Zeus. Hera berpura-pura tidak memercayainya dan menanamkan bibit kecurigaan pada benak Semele. Penasaran, Semele memaksa Zeus untuk membuktikan padanya mengenai kehebatannya dan muncul sebagai pemimpin para dewa. Meskipun Zeus meminta Semele untuk membatalkan keinginannya, namun ia tetap memaksa sehingga Zeus terpaksa setuju. Kemudian Zeus datang pada Semele dengan dilingkari oleh petir dan kilat; namun manusia biasa tidak dapat melihat wujud dewa tanpa samaran secara langsung, mereka akan langsung mati, dan Semele langsung binasa. Zeus menyelamatkan Dionysus yang masih berupa janin dengan menjahitnya di pinggangnya. Beberapa bulan kemudian, Dionysus dilahirkan di Gunung 
Pramnos di pulau Ikaria, dimana Zeus kemudian pergi untuk melepaskan bayi yang telah tumbuh dengan sempurna di pinggangnya. Maka berdasarkan cerita mitologi ini, Dionysus dilahirkan oleh dua orang ibu (Semele dan Zeus) sebelum kelahirannya, maka ia mendapat julukan dimetor yang terkait dengan dua kali kelahirannya.

Sejak awal, masyarakat Yunani kuno mengenal dengan baik karakter aneh dari Dionysus, dan di beberapa kota melarang keras untuk memuja karakter ini. Salah satu penolak keras pengikut dewa Dionysus dan menolak pemujanya adalah Raja Pentheus dari Thebes. Raja ini bahkan mencoba untuk memenjarakan Dionysus, namun rantai belenggu baginya jatuh begitu saja dan pintu penjara tidak dapat ditutup. Dionysus kemudian memberitahu Raja Pentheus bahwa ia dapat mengobservasi secara langsung ritual rahasia para pengikutnya yang ditampilkan di atas sebuah gunung dekat dari kota tersebut, namun Raja Pentheus harus menyamar sebagai wanita. Raja tersebut akhirnya terpancing dengan tawaran tersebut dan mengintai ritual dari para maenad tersebut dengan bersembunyi di atas pohon.

Akan tetapi, para maenad kemudian menemukannya dan di dalam kebingungan dan mabuk, para maenad tersebut mengira bahwa Raja Pentheus merupakan seekor singa dan mencabik-cabik tubuhnya. Selang waktu kemudian, ibu dari Raja Pentheus, yaitu Agave yang merupakan salah satu pemimpin dari maenad, menyadari dengan ngeri bahwa yang telah mereka cabik-cabik bukanlah seekor singa namun tak lain tak bukan adalah putranya sendiri. Setelah pemakaman putranya, Agave bersama dengan orang tuanya, Cadmus dan Harmonia, pergi meninggalkan Thebes dan pergi ke pengasingan.

\section{Berfikir Lateral}

Dalam bukunya Edward de Bono "Berpikir Lateral", adalah bagaimana cara menyelesaian masalah atau solusi dengan metode metode yang tidak umum, atau melalui cara yang banyak orang tidak berpikir kearah sana. Edward De Bono membedakan cara berpikir ini. Berpikir vertikal artinya bagaimana cara kita berpikir secara tradisional atau secara logis. Berpikir vertikal berarti melihat dengan cara pandang yang wajar dari suatu masalah dan mencari solusi dari masalah tersebut sewajarnya.

Pola berpikir lateral berarti kita mencari cara bagaimana menjawab masalah-masalah wajar tersebut dengan sesuatu cara yang berbeda, sehingga akan menghasilkan efek dan hasil yang berbeda pula dari biasanya. Cara mengeksplorasi berbagai pendekatan ini kadang terkesan menentang dari solusi-solusi umum yang dilontarkan pada biasanya. Artinya, berpikir lateral ini berarti tidak menerima dari solusi yang ada seperti umumnya.

Perbedaan berpikir lateral dan berpikir vertical dapat dinyatakan dalam berbagai cara, diantaranya adalah: alternatif (memikirkan banyak jalan keluar pemecahan dari suatu masalah), nonsequentiality (menggabungkan beberapa solusi - solusi yang ada untuk digabungkan dan menjadi suatu jawaban tersendiri), proses seleksi kehancuran (menjawab solusi dengan cara sedikit menyerempet kearah yang hampir dianggap salah), perhatian (melihat dari sesuatu yang tidak biasanya kita pandang).

\section{Rasa}

Dalam menjalani kehidupan, semua manusia pasti pernah merasakan sesuatu hal dengan apa yang dimaksudkan dengan rasa, dimana rasa itu merupakan sebuah saripati dari sesuatu, sebuah esensi yang dirasakan oleh manusia dalam keterkaitan dengan sebuah penilaian inti atau pokok yang terpenting akan sesuatu. Sebut saja seperti rasa sakit hati, jatuh cinta, marah, cemas, bahagia, takut, dan sebagainya. Semua itu mengandung arti yang sulit untuk diungkapkan secara pasti dalam bahasa. 
Rasa dapat dikatakan sebagai daya penggerak dan daya kreasi manusia, yang hanya dapat disugestikan, atau dialami secara mendalam tanpa bisa dideskripsikan. Ketika seorang pelukis yang menggunakan rasa pada saat menggoreskan kuasnya akan menghasilkan lukisan yang sangat berarti dan bermakna dibanding dengan lukisan lukisan lain yang hanya merupakan kumpulan dari goresan goresan tak berarti. Seorang pegawai yang bekerja dengan penuh rasa bahagia dan tanggung jawab akan merasakan hasil yang sangat memuaskan dibanding dengan orang orang yang hanya bekerja karena terpaksa. Seorang aktor yang profesional akan memerankan perannya dengan rasa, dengan menjiwai karakter yang diperankan. Forest Whitaker, seorang aktor yang sangat menjiwai perannya dalam film The Last King of Scotland sebagai Presiden Uganda, Idi Amin. Karakter Idi Amin sangat merasuki Whitaker, yang mampu menghasilkan sebuah film layar lebar yang sangat menarik untuk dilihat dan akhirnya mendapatkan piala Oscar karena peran tersebut. Karena sangat menjiwai,perannya, Forest Whitaker memerlukan waktu yang cukup lama untuk melepas karakter Idi Amin dalam kehidupan yang sebenarnya.

\section{SIMPULAN}

Dalam dunia seni pun, pengamatan dapat terjadi. Pengalaman dalam pengamatan secara cermat dalam sebuah desain maka akan ditemukan insight sebuah karya seni, yaitu suatu pengalaman baru yang sifatnya esensial dan fundamental. Pengamatan ini bertujuan untuk menemukan intisari dalam sebuah makna karya seni yang dihasilkan. Pada sebuah karya seni, harus memiliki insight yang bersifat unik, sesuatu yang baru yang tidak pernah sama dengan yang pernah tercipta, karena insight merupakan modal utama harus dimiliki dalam menciptakan sebuah karya seni yang baik. Insight bisa didapatkan dari pengalaman dalam pengamatan sebuah objek secara mendalam dan terus menerus. Dalam sebuah karya seni, harus dimiliki insight yang bersifat unik, sesuatu yang baru yang tidak pernah sama dengan yang pernah tercipta karena insight merupakan modal utama harus dimiliki dalam menciptakan sebuah karya seni yang baik. Insight bisa didapatkan dari pengalaman dalam pengamatan sebuah objek secara mendalam dan terus menerus.

\section{DAFTAR PUSTAKA}

Cotterell, Arthur and Storm, Rachel. (2007). The Ultimate Encyclopedia of Mythology. London: Annes Publishing Ltd, Hermes House.

De Bono, E. (1991). Berfikir Lateral, Diterjemahkan oleh Suyoto, Jakarta: Erlangga

Marianto, M. D. (2006). Quantum Seni. Semarang: Dahar Prize.

(2011). Menempa Quanta Mengurai Seni. Yogyakarta: Badan Penerbit Institut Seni Indonesia Yogyakarta

Zohar, D. (1990). The Quantum Self. New York: William Morrow and Company. 